\title{
In Vitro Antioxidant Activity of Enicostemma axillare
}

\author{
Jaishree Vaijanathappa, Shrishailappa Badami, ${ }^{*}$ and Suresh Bhojraj \\ Department of Pharmaceutical Chemistry, JSS College of Pharmacy, Rocklands, Post Box No.-20 Ootacamund-643 001, Tamil Nadu, \\ India
}

(Received October 19, 2007; Accepted April 5, 2008)

\begin{abstract}
Four successive extracts of the whole plant of Enicostemma axillare (E. axillare), were examined for in vitro antioxidant activity using nine different methods. In the 2,2'-azino-bis(3-ethylbenzo-thiazoline-6-sulfonic acid) diammonium salt (ABTS) method, all the four extracts of $E$. axillare showed potent antioxidant activity with $\mathrm{IC}_{50}$ values ranging from 13.26 to $24.36 \mu \mathrm{g} / \mathrm{ml}$. The chloroform extract has shown potent antioxidant activity in $\mathrm{H}_{2} \mathrm{O}_{2}$, nitric oxide, and hydroxyl radical using the deoxyribose and lipid peroxidation methods, with $\mathrm{IC}_{50}$ values of $16.99 \pm 0.38,60.66 \pm 0.30,25.06 \pm 0.12$, and $94.66 \pm 2.40 \mu \mathrm{g} / \mathrm{ml}$, respectively. Potent activity was also observed for the petroleum ether extract with the deoxyribose, $p$-nitroso dimethyl aniline ( $p$-NDA), and $\mathrm{H}_{2} \mathrm{O}_{2}$ methods and for the ethyl acetate extract with the $\mathrm{H}_{2} \mathrm{O}_{2}$ and nitric oxide methods. All extracts showed moderate total antioxidant capacity using the phosphomolybdenum method. The activity was not correlated with the total phenol content of the extracts.
\end{abstract}

Key words _ Enicostemma axillare, antioxidant, total phenol, Gentianaceae

\section{INTRODUCTION}

Enicostemma axillare (E. axillare) Lam Raynal (synonym-Enicostemma littorale Blume, Gentianaceae) is a perennial herb found throughout India and common in coastal areas. The plant is used in folk medicine to treat diabetes mellitus, rheumatism, abdominal ulcers, hernia, swelling, itching and insect poisoning. ${ }^{1)}$ Its antiinflammatory, ${ }^{2)}$ hypoglycemic, ${ }^{3-5)}$ and anticancer ${ }^{6)}$ activities have been reported. These reported activities and many of the ethnomedical uses of the plant are related to its antioxidant activity. Swertiamarin, alkaloids, steroids, triterpenoids, saponins, flavonoids, xanthones, phenolic acids, etc. were isolated from the plant. ${ }^{4)}$ Many such compounds have protective effects due to their antioxidant properties. ${ }^{7)}$ Several antioxidants of plant origin were experimentally confirmed and used as effective protective agents against free radical-mediated toxicity. ${ }^{8}$ Studies have implicated the role of free radicals in the causation of inflammation, diabetes and cancer. ${ }^{9)}$ Hence, the present study focused on the evaluation of the antioxidant activity of E. axillare

\footnotetext{
*To whom correspondence should be addressed: Department of Pharmaceutical Chemistry, JSS College of Pharmacy, Rocklands, Post Box No.-20 Ootacamund-643 001, Tamil Nadu, India. Tel.: +91-423-2443393; Fax: +91-423-2442937; E-mail: shribadami@rediffmail.com
}

using nine different methods.

\section{MATERIALS AND METHODS}

Plant Collection — The whole plants of E. axillare were collected during full bloom in September 2005 from Bidar district, Karnataka, India, and authenticated by Dr. S. Rajan, Medicinal Plants Survey and Collection Unit, Government Arts College Ootacamund, India.

Extraction and Phytochemical Analysis — The whole plants were shade-dried, powdered, and extracted $(300 \mathrm{~g})$ successively and separately with 1.51 each of petroleum ether $\left(60-80^{\circ} \mathrm{C}\right)$, chloroform, ethyl acetate, and methanol in a Soxhlet extractor for $18-20 \mathrm{hr}$. The extracts were concentrated to dryness under reduced pressure and controlled temperature $\left(40-50^{\circ} \mathrm{C}\right)$ in a rotavapor. All the extracts were subjected to qualitative chemical tests for the identification of various phytoconstituents. ${ }^{10)}$ The total phenol content was determined using Folin-Ciocalteu reagent, ${ }^{11)}$ and the total flavonol content was estimated using the aluminum chloride method. ${ }^{12)}$

Preparation of Test and Standard Solutions Four successive extracts of E. axillare and the standard antioxidants [ascorbic acid, rutin, butylated hydroxyanisole (BHA)] were dissolved in distilled 
dimethyl sulfoxide (DMSO) separately and used for in vitro antioxidant assays with eight different methods, excluding the hydrogen peroxide method. For the hydrogen peroxide method, in which DMSO interferes, the extracts and standards were dissolved in distilled methanol before use. The stock solutions were serially diluted with the respective solvents to obtain lower dilutions.

In Vitro Antioxidant Activity — In all these methods, a specific concentration of the extract or standard solution was used to give a final concentration of $1000 \mu \mathrm{g} / \mathrm{ml}$ to $0.45 \mu \mathrm{g} / \mathrm{ml}$. Absorbance was measured against a blank solution that contained the extract or standard, but without the reagent. A control experiment was performed without adding the extract or standard. The $\mathrm{IC}_{50}$ value, which is the concentration of the sample required to scavenge $50 \%$ of free radicals, was calculated.

Scavenging of 2,2'-Azino-bis(3-EthylbenzoThiazoline-6-Sulfonic Acid) Diammonium Salt (ABTS) Radical Cation — To $0.2 \mathrm{ml}$ of various concentrations of the extract or standard solution, $1.0 \mathrm{ml}$ of distilled DMSO and $0.16 \mathrm{ml}$ of ABTS solution $(2 \mathrm{mM})$ were added and incubated for $20 \mathrm{~min}$. Absorbance of these solutions was measured spectrophotometrically at $734 \mathrm{~nm} .{ }^{13}$ )

\section{2,2-Diphenyl-1-Picryl Hydrazyl (DPPH) Radical}

Scavenging Method — The extract or standard solution $(10 \mu \mathrm{l})$ was added to DPPH in methanol solution $(100 \mu \mathrm{M}, 200 \mu \mathrm{l})$ in a 96 -well microtiter plate (Tarsons, Kolkata, India). After incubation at $37^{\circ} \mathrm{C}$ for $30 \mathrm{~min}$, the absorbance of each solution was determined at $490 \mathrm{~nm}^{13}$ )

Scavenging of Hydroxyl Radical in the Deoxyribose Method — To the reaction mixture containing deoxyribose $(3 \mathrm{mM}, 0.2 \mathrm{ml})$, ferric chloride $(0.1 \mathrm{mM}, 0.2 \mathrm{ml})$, ethylenediaminetetraacetic acid disodium salt (EDTA) $(0.1 \mathrm{mM}, 0.2 \mathrm{ml})$, ascorbic acid $(0.1 \mathrm{mM}, 0.2 \mathrm{ml})$, and hydrogen peroxide $(2 \mathrm{mM}, 0.2 \mathrm{ml})$ in phosphate buffer $(\mathrm{pH}, 7.4$, $20 \mathrm{mM}$ ), was added $0.2 \mathrm{ml}$ of various concentrations of the extract or standard in DMSO to give a total volume of $1.2 \mathrm{ml}$. The solutions were then incubated for $30 \mathrm{~min}$ at $37^{\circ} \mathrm{C}$. After incubation, ice-cold trichloroacetic acid $(0.2 \mathrm{ml}, 15 \% \mathrm{w} / \mathrm{v})$, and thiobarbituric acid $(0.2 \mathrm{ml}, 1 \% \mathrm{w} / \mathrm{v})$ in $0.25 \mathrm{~N}$ hydrochloric acid were added. The reaction mixture was kept in a boiling water bath for $30 \mathrm{~min}$, cooled, and the absorbance was measured at $532 \mathrm{~nm}^{13)}$

Scavenging of Hydroxyl Radical in the $p$ Nitroso Dimethyl Aniline ( $p$-NDA) Method To a solution containing ferric chloride $(0.1 \mathrm{mM}$,
$0.5 \mathrm{ml})$, EDTA $(0.1 \mathrm{mM}, 0.5 \mathrm{ml})$, ascorbic acid $(0.1 \mathrm{mM}, 0.5 \mathrm{ml}), \mathrm{H}_{2} \mathrm{O}_{2}(2 \mathrm{mM}, 0.5 \mathrm{ml})$, and $p$ NDA $(0.01 \mathrm{mM}, 0.5 \mathrm{ml})$ in phosphate buffer $(\mathrm{pH}$ $7.4,20 \mathrm{mM}$ ) were added various concentrations of the extract or standard in distilled DMSO $(0.5 \mathrm{ml})$ to produce a final volume of $3 \mathrm{ml}$. Absorbance was measured at $440 \mathrm{~nm}^{14)}$

Scavenging of Hydrogen Peroxide — A solution of hydrogen peroxide $(20 \mathrm{mM})$ was prepared in Phosphate buffer saline (PBS) (pH 7.4). Various concentrations of the extract or standard in methanol $(1 \mathrm{ml})$ were added to $2 \mathrm{ml}$ of hydrogen peroxide solution in PBS. After $10 \mathrm{~min}$, the absorbance was measured at $230 \mathrm{~nm} .{ }^{15}$ )

Nitric Oxide Radical Inhibition Assay — The reaction mixture $(6 \mathrm{ml})$ containing sodium nitroprusside $(10 \mathrm{mM}, 4 \mathrm{ml})$, PBS $(1 \mathrm{ml})$, and the extract or standard solution $(1 \mathrm{ml})$ was incubated at $25^{\circ} \mathrm{C}$ for $150 \mathrm{~min}$. After incubation, $0.5 \mathrm{ml}$ of the reaction mixture was removed, $1 \mathrm{ml}$ of sulphanilic acid reagent $(0.33 \%$ in $20 \%$ glacial acetic acid) was mixed and allowed to stand for $5 \mathrm{~min}$ for completion of the diazotization reaction, $1 \mathrm{ml}$ of naphthyl ethylene diamine dihydrochloride was added, and the mixture was allowed to stand for $30 \mathrm{~min}$ in diffused light. The absorbance was measured at $540 \mathrm{~nm} .{ }^{13}$ ) Scavenging of Superoxide Radical with the Alkaline DMSO Method — To the reaction mixture containing $0.1 \mathrm{ml}$ of nitro blue tetrazolium $(1 \mathrm{mg} / \mathrm{ml}$ in DMSO) and $0.3 \mathrm{ml}$ of the extract or standard in DMSO was added $1 \mathrm{ml}$ of alkaline DMSO $(1 \mathrm{ml}$ of DMSO containing sodium hydroxide $5 \mathrm{mM}$ in $0.1 \mathrm{ml}$ of water) to give a final volume of $1.4 \mathrm{ml}$, and the absorbance was measured at $560 \mathrm{~nm} .{ }^{14)}$

Evaluation of Total Antioxidant Capacity An aliquot of $0.1 \mathrm{ml}$ of extract or standard solution in DMSO was combined with $1 \mathrm{ml}$ of reagent solution (sulfuric acid $0.6 \mathrm{M}$, sodium phosphate $28 \mathrm{mM}$, and ammonium molybdate $4 \mathrm{mM}$ ) in an Eppendorff tube. The tubes were capped, incubated in a water bath at $95^{\circ} \mathrm{C}$ for $90 \mathrm{~min}$, cooled to room temperature, and the absorbance of each solution was measured at $695 \mathrm{~nm} .{ }^{16)}$ The results are expressed as millimolar equivalents of ascorbic acid.

Lipid Peroxidation Inhibitory Activity — Egg yolk was separated and washed with acetone until the yellow color was removed. The creamy white powder obtained was egg lectin. Lipid peroxidation was induced by adding ferric chloride $10 \mu \mathrm{l}(400 \mathrm{mM})$ and L-ascorbic acid $10 \mu \mathrm{l}(400 \mathrm{mM})$ to a mixture containing egg lectin $(3 \mathrm{mg} / \mathrm{ml})$ in phosphate buffer solution and different concentra- 
Table 1. Extraction, Phytochemical Analysis, and In Vitro Antioxidant Activity of E. axillare in Different Methods

\begin{tabular}{|c|c|c|c|c|}
\hline \multirow[t]{2}{*}{ Extract/Standard } & \multicolumn{4}{|c|}{ Extraction } \\
\hline & $\begin{array}{c}\text { Characterstics } \\
\text { (\% yield })\end{array}$ & $\begin{array}{l}\text { Phytochemical } \\
\text { analysis }\end{array}$ & $\begin{array}{c}\text { Total phenol } \\
\mathrm{mg} / \mathrm{g}^{a, b)}\end{array}$ & $\begin{array}{c}\text { Total flavonol } \\
\mathrm{mg} / \mathrm{g}^{a, c)}\end{array}$ \\
\hline $\begin{array}{l}\text { Petroleum ether } \\
\text { extract }\end{array}$ & $\begin{array}{l}\text { Blackish green } \\
\text { sticky residue } \\
(2.4 \%)\end{array}$ & Steroids, triterpenoids & - & - \\
\hline $\begin{array}{l}\text { Chloroform } \\
\text { extract }\end{array}$ & $\begin{array}{l}\text { Blackish green } \\
\text { sticky residue } \\
(2.8 \%)\end{array}$ & $\begin{array}{l}\text { Alkaloids, flavonoids, } \\
\text { phenols, triterpenoids }\end{array}$ & $80.00 \pm 1.15$ & $17.73 \pm 0.81$ \\
\hline $\begin{array}{l}\text { Ethyl acetate } \\
\text { extract }\end{array}$ & $\begin{array}{l}\text { Brown semisolid } \\
(3 \%)\end{array}$ & $\begin{array}{l}\text { Flavonoids, phenols, } \\
\text { saponins, iridoid gly- } \\
\text { cosides, tannins }\end{array}$ & $73.33 \pm 5.81$ & $28.80 \pm 0.83$ \\
\hline $\begin{array}{l}\text { Methanol } \\
\text { extract }\end{array}$ & $\begin{array}{l}\text { Brown semisolid } \\
(4 \%)\end{array}$ & $\begin{array}{l}\text { Alkaloids, flavonoids, } \\
\text { phenols, iridoid gly- } \\
\text { cosides, tannins }\end{array}$ & $97.33 \pm 4.80$ & $31.33 \pm 2.19$ \\
\hline Ascorbic acid & & & - & - \\
\hline Rutin & & & - & - \\
\hline BHA & & & - & - \\
\hline \multirow[t]{2}{*}{ Extract/Standard } & \multicolumn{4}{|c|}{$\mathrm{IC}_{50}$ values $\pm \mathrm{SEM}(\mu \mathrm{g} / \mathrm{ml})^{a, e)}$ by method } \\
\hline & ABTS & DPPH & Deoxyribose & $p$-NDA \\
\hline $\begin{array}{l}\text { Petroleum ether } \\
\text { extract }\end{array}$ & $13.26 \pm 0.49$ & $460.73 \pm 9.65$ & $54.30 \pm 1.42$ & $119.00 \pm 2.08$ \\
\hline $\begin{array}{l}\text { Chloroform } \\
\text { extract }\end{array}$ & $24.36 \pm 0.29$ & $396.60 \pm 3.01$ & $25.06 \pm 0.12$ & $209.66 \pm 0.88$ \\
\hline $\begin{array}{l}\text { Ethyl acetate } \\
\text { extract }\end{array}$ & $13.86 \pm 1.33$ & $113.16 \pm 7.00$ & $149.33 \pm 2.04$ & $>1000$ \\
\hline $\begin{array}{l}\text { Methanol } \\
\text { extract }\end{array}$ & $18.48 \pm 0.56$ & $325.30 \pm 5.68$ & $>1000$ & $>1000$ \\
\hline Ascorbic acid & $11.25 \pm 0.49$ & $2.69 \pm 0.05$ & - & $>1000$ \\
\hline Rutin & $0.52 \pm 0.05$ & $3.91 \pm 0.10$ & - & $>1000$ \\
\hline BHA & - & - & $86.16 \pm 4.04$ & $>1000$ \\
\hline \multirow[t]{2}{*}{ Extract/Standard } & \multicolumn{3}{|c|}{$\mathrm{IC}_{50}$ values $\pm \operatorname{SEM}(\mu \mathrm{g} / \mathrm{ml})^{a, e)}$ by method } & Total anti \\
\hline & $\mathrm{H}_{2} \mathrm{O}_{2}$ & Nitric oxide & $\begin{array}{c}\text { Lipid } \\
\text { peroxi-dation }\end{array}$ & oxidant capacity $^{d)}$ \\
\hline $\begin{array}{l}\text { Petroleum ether } \\
\text { extract }\end{array}$ & $37.76 \pm 5.14$ & $194.50 \pm 0.28$ & $100.00 \pm 1.52$ & $0.63 \pm 0.03$ \\
\hline $\begin{array}{l}\text { Chloroform } \\
\text { extract }\end{array}$ & $16.99 \pm 0.38$ & $60.66 \pm 0.30$ & $94.66 \pm 2.40$ & $0.72 \pm 0.01$ \\
\hline $\begin{array}{l}\text { Ethyl acetate } \\
\text { extract }\end{array}$ & $24.03 \pm 1.41$ & $69.47 \pm 0.63$ & $>1000$ & $0.85 \pm 0.02$ \\
\hline $\begin{array}{l}\text { Methanol } \\
\text { extract }\end{array}$ & $60.86 \pm 0.20$ & $219.90 \pm 2.68$ & $>1000$ & $0.59 \pm 0.04$ \\
\hline Ascorbic acid & $187.33 \pm 3.93$ & - & - & - \\
\hline Rutin & $36.66 \pm 0.22$ & $65.44 \pm 2.56$ & - & - \\
\hline BHA & $24.88 \pm 0.16$ & - & $112.66 \pm 1.32$ & - \\
\hline
\end{tabular}

a) Average of three determinations, mean $\pm \mathrm{SEM}, b$ ) gallic acid, and $c$ ) rutin, equivalent in $\mathrm{mg} / \mathrm{g}$ of the extract. $d$ ) The total antioxidant capacity expressed as millimolar equivalents of ascorbic acid. In the alkaline DMSO method, no extract showed activity. 
tions of the extracts $(100 \mu \mathrm{l})$. After incubation for $1 \mathrm{hr}$ at $37^{\circ} \mathrm{C}$, the reaction was stopped by adding $2 \mathrm{ml}$ of $0.25 \mathrm{~N}$ hydrochloric acid containing $15 \%$ w/v trichloroacetic acid and $0.375 \%$ w/v thiobarbituric acid, boiled for $15 \mathrm{~min}$, cooled, centrifuged, and absorbance of the supernatant was measured at $532 \mathrm{~nm}^{17)}$

\section{RESULTS AND DISCUSSION}

In the ABTS method, all four extracts of E. axillare showed potent antioxidant activity, with $\mathrm{IC}_{50}$ values ranging from 13.26 to $24.36 \mu \mathrm{g} / \mathrm{ml}$ (Table 1). However, the standards rutin and ascorbic acid exhibited better results with lower $\mathrm{IC}_{50}$ values. In the $\mathrm{H}_{2} \mathrm{O}_{2}$ method, the petroleum ether, chloroform, and ethyl acetate extracts showed potent activity greater than or comparable to the standard rutin, and all the extracts showed more potent activity when compared with standard ascorbic acid. In the nitric oxide method, the chloroform and ethyl acetate extract showed comparable activity to that of the standard rutin. In the deoxyribose, $p$-NDA, and lipid peroxidation methods, the petroleum ether and chloroform extracts showed more potent or comparable antioxidant activity to those of the standards used. In the alkaline DMSO method, since the $\mathrm{IC}_{50}$ values were found to be greater than $1000 \mu \mathrm{g} / \mathrm{ml}$, all the extracts were found to be inactive. All the extracts exhibited moderate total antioxidant capacity in the phosphomolybdenum method and low activity in the DPPH method.

Free radical and reactive oxygen species are well known inducers of cellular and tissue pathogenesis leading to several human diseases, such as cancer, inflammatory disorders, and diabetes mellitus, as well as in the aging process. ${ }^{18)}$ Many plant species with antioxidant activities act as protective agents against these diseases. ${ }^{7}$ In the present study, potent antioxidant activity was observed using many methods for all extracts of E. axillare. Among the extracts, the petroleum ether, chloroform, and ethyl acetate extracts exhibited potent activities. However, the efficacy of each extract differed against various free radicals depending on the specific assay methodology, reflecting the complexity of the mechanisms and diversity of the chemical nature of the phytoconstituents present.

The total phenol and flavonol contents in the methanol extract were found to be higher than in the other extracts. However, the methanol extract was found to be the least active among the four extracts. Hence, no correlation exists between the observed antioxidant activity and total phenol and flavonol contents. The preliminary phytochemical analysis indicated the presence of steroids and triterpenoids in the petroleum ether extract; alkaloids, flavonoids, phenols and triterpenoids in the chloroform extract; flavonoids, phenols, saponins, iridoid glycosides, and tannins in the ethyl acetate extract; and alkaloids, phenols, saponins, iridoid glycosides, and tannins in the methanol extract. The observed antioxidant activity may be due to the presence of any of these constituents in the extracts. E. axillare is known to have potent antiinflammatory, antidiabetic, and anticancer activities. ${ }^{3-6)}$ These reported activities may due to the antioxidant properties of the plant. However, further studies are required to confirm this.

In conclusion, the successive petroleum ether, chloroform, and ethyl acetate extracts of E. axillare exhibited potent in vitro antioxidant activity. The plant merits further investigation in animal models to confirm its antioxidant activity and to isolate the active constituents, especially due to their non-polar nature.

\section{REFERENCES}

1) Kirtikar, K. R. and Basu, B. D. (1999) Indian Medicinal Plants, 2nd edition, Bishen Sing Mahendra Pal Sing, Dehradun, pp. 1655-1656.

2) Sadique, J., Chandra, T., Thenmozhi, V. and Elango, V. (1987) The anti-inflammatory activity Enicostemma littorale and Mullogo cerviana. Biochem. Med. Metab. Biol., 37, 167-176.

3) Jyoti, M., Vasu, V. T., Ravikumar, A. and Sarita, G. (2002) Glucose lowering effect of aqueous extract of Enicostemma littorale Blume in diabetes: a possible mechanism of action. J. Ethnopharmacol., 81, 317320.

4) Murali, B., Upadhyaya, U. M. and Goyal, R. K. (2002) Effect of chronic treatment with Enicostemma littorale Blume in non insulin dependent diabetic (NIDDM) rats. J. Ethnopharmacol., 81, 199-204.

5) Jyoti, M., Vasu, V. T. and Guptam, S. (2003) Dosedependent hypoglycemic effect of aqeous extract of Enicostemma littorale Blume in alloxan-induced diabetic rats. Phytomedicine, 10, 196-199.

6) Kavimani, S. and Manisenthilkumar, K. T. (2000) Effect of methanolic extract of Enicostemma lit- 
torale on Dalton's ascitic lymphoma. J. Ethnopharmacol., 71, 349-352.

7) Wargovich, M. J., Woods, C., Holli, D. M. and Zander, M. E. (2001) Herbals, cancer prevention and health. J. Nutr., 131, 3034S-3036S.

8) Heba, H. M., Hafez, F. H. and Nadia, M. F. (2006) Silymarin modulates cisplatin-induced oxidative stress and hepatotoxicity in rats. J. Biochem. Mol. Biol., 39, 656-661.

9) Cheeseman, K. H. and Slater, T. F. (1993) Free Radicals in Medicine, vol.49, Churchill Livingstone, London, p. 491.

10) Kokate, C. K., Purohit, A. P. and Gokhale, S. B. (2003) Pharmacognosy, 7th edition, Nirali Prakashan, Pune, p. 105.

11) Sadasivam, S. and Manikam, A. (1992) Biochemical Methods for Agricultural Sciences, Wiley Eastern Limited, New Delhi, p. 187.

12) Woisky, R. and Salatino, A. (1998) Analysis of propilis: some parameters and procedures for chemical quality control. J. Agric. Res., 37, 99-105.

13) Badami, S., Om Prakash., Dongre, S. H. and Suresh, B. (2005) In vitro antioxidant properties of Solanum pseudocapsicum leaf extracts. Indian J. Pharmacol., 37B, 251-252.

14) Kerri, E. and Rao, M. N. A. (1990) Oxygen radical scavenging activity of curcumin. Int. J. Pharm., 58, 237-240.

15) Jayaprakasha, G. K., Jaganmohan Rao, L. and Sakariah, K. K. (2004) Antioxidant activities of flavidin in different in vitro model systems. Bioorg. Med. Chem., 12, 5141-5146.

16) Huong, N. T. T., Malsumato, K., Kasai, R., Yamasaki, K. and Watana, B. (1998) In vitro antioxidant activity of Vietnamese ginseng saponin and its components. Biol. Pharm. Bull., 21, 978-981.

17) Duh, P. D., Yen, G. C., Yen, W. J. and Chang, L. W. (2001) Antioxidant effects of water extracts from barley (Hordeum vulgare L.) prepared under different roasting temperatures. J. Agric. Food Chem., 49, $1455-1463$.

18) Aviram, M. (2000) Review of human studies on oxidative damage and antioxidant protection related to cardiovascular diseases. Free Radic. Res., 33, S85S97. 